\title{
IMPLEMENTASI PEMADAM KEBAKARAN OTOMATIS PADA RUANGAN MENGGUNAKAN PENDETEKSI ASAP SUHU RUANGAN DAN SENSOR API BERBASIS ESP32 DENGAN METODE FUZZY SUGENO DAN INTERNET OF THINGS (IOT)
}

\author{
Ervin Setyawan ${ }^{1}$, Umi Chotijah ${ }^{2}$, Henny Dwi Bhakti ${ }^{3}$ \\ 1,2,3) Universitas Muhammadiyah Gresik \\ Fakultas Teknik Universitas Muhammadiyah Gresik \\ Jl. Sumatera 101 Gresik Kota Baru (GKB), Randuagung, 61121 \\ Telp.(031) 3951414 , Faks. (031) 3952585 \\ E-mail: ervinsetyawan.id@gmail.com ${ }^{1}$, umichotijah@umg.ac.id ${ }^{2}$,hennydwi@umg.ac.id
}

\begin{abstract}
ABSTRAK
Peristiwa kebakaran seringkali terlihat sangat menyeramkan. Beberapa berita mengungkapkan bahwa kebakaran memang terjadi begitu saja dan tidak mengenal waktu. Dilansir menurut beberapa fakta yang ada, kebakaran terjadi karena kelalaian manusia dan juga gangguan sebuah sistem. Kebakaran merupakan reaksi antar komponen yang saling mendukung menyebabkan terjadinya api.

Pengimplementasian pemadam kebakaran ruangan menggunakan pendeteksi asap suhu ruangan dan sensor api memang perlu dipikirkan dengan baik. Semua ruangan baik kantor, sekolah, laboratorium, dan lain sebagainya memang membutuhkan alat sensor yang canggih. Penggunaan alat dengan teknologi canggih yang ada tentunya menciptakan inovasi terbaru dalam penyiraman otomatis pada kebakaran api di dalam ruangan.

Berdasar pada cara terakhir dalam upaya pemadam kebakaran, penulis coba menerapkan sebuah sistem cerdas pada pemadam kebakaran dengan menggunakan sensor suhu DS18B20 yang berfungsi sebagai sensor perubahan suhu, sensor asap MQ2 sebagai penangkap jumlah asap, dan sensor api sebagai pendeteksi adanya jarak api terhadap sensor, dengan menambahkan metode fuzzy sugeno sebagai pengontrol pompa.
\end{abstract}

Kata Kunci : Fuzzy Sugeno, Pemadam Kebakaran, Internet Of Things.

\section{ABSTRACT}

Fire events often look very scary. Some news revealed that the fire did happen just like that and did not know the time. Reported according to some existing facts, the fire occurred due to human negligence and also a system disturbance. Fire is a reaction between components that support each other causing a fire.

The implementation of a room fire extinguisher using a room temperature smoke detector and a fire sensor does need to be thought out carefully. All rooms, whether offices, schools, laboratories, and so on, require sophisticated sensor equipment. The use of tools with existing advanced technology certainly creates the latest innovations in automatic watering of indoor fires.

Based on the last method in firefighting efforts, the author tries to implement an intelligent system for firefighters using the DS18B20 temperature sensor which functions as a temperature change sensor, the MQ2 smoke sensor as a catcher for the amount of smoke, and a fire sensor as a detector of the distance of fire to the sensor, with added the fuzzy sugeno method as a pump controller.

Keywords : Fuzzy Sugeno, Firefighters, Internet Of Things.

\section{PENDAHULUAN}

Peristiwa kebakaran seringkali terlihat sangat menyeramkan. Beberapa berita mengungkapkan bahwa kebakaran memang terjadi begitu saja dan tidak mengenal waktu.
Dilansir menurut beberapa fakta yang ada, kebakaran terjadi karena kelalaian manusia dan juga gangguan sebuah sistem. Kebakaran merupakan reaksi antar komponen yang saling 
INDEXIA: Informatic and Computational Intelegent Journal

Ervin Setyawan, Umi Chotijah, Henny Dwi Bhakti

Implementasi Pemadam Kebakaran Otomatis Pada Ruangan Menggunakan Pendeteksi Asap Suhu

Ruangan Dan Sensor Api Berbasis Esp32 Dengan Metode Fuzzy Sugeno Dan Internet Of Things (lot)

mendukung menyebabkan terjadinya api.

Kebakaran tidak langsung terjadi dalam keadaan

besar, kebanyakan kebakaran diawali dari api

kecil, kemudian membesar (Romadhon, 2018)

[1]. Tidak sedikit juga korban jiwa yang tewas dan luka-luka akibat kebakaran.

Studi kasus dalam konteks ini bisa dikaitkan dengan peristiwa kebakaran di Pasar Gresik, Jawa Timur pada bulan februari tahun 2017. Kebakaran ini terjadi diduga karena korsleting hubungan arus listrik. Kebakaran menimpa sekitar 20 kios yang ada di Pasar Gresik. Pemadam kebakaran dari wilayah Gresik juga tidak sanggup untuk memadamkan api dan meminta bantuan dari Surabaya terkait hal tersebut (Arfah, 2017) [2].

Dari studi kasus tersebut dapat dijadikan pembelajaran dan berpikir untuk menemukan solusi yang tepat. Pengimplementasian pemadam kebakaran ruangan menggunakan pendeteksi asap suhu ruangan dan sensor api memang perlu dipikirkan dengan baik. Semua ruangan baik kantor, sekolah, laboratorium, dan lain sebagainya memang membutuhkan alat sensor yang canggih. Penggunaan alat dengan teknologi canggih yang ada tentunya menciptakan inovasi terbaru dalam penyiraman otomatis pada kebakaran api di dalam ruangan.

Di era yang serba canggih seperti ini, teknologi membawa dampak positif untuk merealisasikan hal tersebut. Alat yang digunakan untuk IoT adalah ESP32, ESP32 adalah alat yang digunakan untuk menyambungkan ke internet sehingga bisa digunakan dalam projek IoT. ESP32 dilengkapi dengan fitur Wi-Fi dan Bluetooth. Salah satu gagasan untuk solusi dari permasalahan kebakaran adalah implementasi ESP32 dengan menggunakan metode fuzzy Sugeno dan internet of things (IoT) (Supriyadi, 2020) [3]. Alat yang dibutuhkan dalam mendeteksi kebakaran di dalam ruangan adalah penggunaan sistem monitoring dengan menggunakan ESP32, Sensor MQ-2 (pendeteksi asap kebakaran), dan sensor DS18B20 (pendeteksi suhu kebakaran). Penggunaan ESP32 juga tidak lepas dari penerapan logika Fuzzy. Logika Fuzzy digunakan sebagai pemikiran dasar dalam penentuan keluaran dalam sistem alam, pompa air, atau kipas. Data yang ada nantinya akan dianalisa menggunakan logika Fuzzy. Data masukan pertama didapatkan dari penggunaan sensor suhu, sensor asap dan sensor api. Logika Fuzzy yang digunakan dalam hal ini menggunakan penerapan metode Sugeno. Penerapan metode Sugeno ini hampir sama dengan penalaran Mamdani. Hanya saja output yang digunakan di dalam sistem tidak berupa

himpunan Fuzzy melainkan konstanta atau persamaan Linier.

Selain itu, Perancangan sistem pendeteksi kebakaran ruangan dengan ESP32 berbasis IoT juga sangat diperlukan. Sistem ini akan bekerja secara otomatis dan mendeteksi dengan cepat untuk menghindari kemungkinan luasnya api. Sistem IoT ini dalam pengimplementasiannya menggunakan argumentasi pemrograman. Setiap argumen dapat menghasilkan interaksi pada mesin yang sudah terkoneksi dengan otomatis tanpa bantuan jarak dan manusia.

Metode fuzzy sugeno dipilih karena metode ini mampu menghitung data yang samar menjadi tidak samar. Nantinya data yang telah diterima oleh sensor akan di sederhanakan dengan perhitungan metode fuzzy sugeno, dan hasil data yang diperoleh akan di jalankan ke output pompa, sehingga nantinya hasil dari pompa tersebut bisa menjadi antisipasi masyarakat dalam sebuah kebakaran yang akan terjadi.

\section{LANDASAN TEORI Kebakaran}

Kebakaran merupakan hal yang sangat mengerikan. Kebakaran terjadi karena adanya gesekan antara listrik maupun kesalahan umum. Tidak sedikit terjadinya kebakaran terutama didalam ruangan bangunan yang belum memadai adanya sensor.

Sumber kebakaran diawali dengan api yang kecil hingga membesar dan tidak bisa cepat terdeteksinya kebakaran mengakibatkan dampak yang membuat api menyala sangat besar. Teori dalam kebakaran umumnya digambarkan dalam fire triangle (segitiga api). Dimana teori ini dikenal dengan adanya sebuah elemen-elemen yang terjadinya dalam proses pembentukan kebakaran. Elemen ini terdiri dari: panas, oksigen, dan bahan baku material.

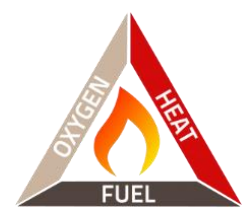

Gambar 1. Fire triangle

\section{Panas}

Panas suhu dalam ruangan memicu terjadinya penyebab inti dalam kebakaran. Sumber panas berasal dari api, matahari, gesekan listrik, api las, reaksi kimia eksotermis, gas yang dikompresi.

\section{Oksigen}


INDEXIA: Informatic and Computational Intelegent Journal

Ervin Setyawan, Umi Chotijah, Henny Dwi Bhakti

Implementasi Pemadam Kebakaran Otomatis Pada Ruangan Menggunakan Pendeteksi Asap Suhu

Ruangan Dan Sensor Api Berbasis Esp32 Dengan Metode Fuzzy Sugeno Dan Internet Of Things (lot)

Sumber oksigen dari udara, dimana diperlukan paling sedikit sekitar $15 \%$ volume oksigen dalam udara supaya terjadi pembakaran. Udara normal di dalam atmosfir kita mengandung $21 \%$ volume oksigen. Ada sebagian bahan bakar memiliki cukup banyak kandungan oksigen membuat adanya pembakaran.

\section{Bahan Bakar}

Bahan bakar adalah semua benda yang bisa membuat terjadinya pembakaran. Ada tiga wujud bahan bakar, yaitu padat, cair dan gas. Untuk benda padat dan cair diperlukan panas pendahuluan untuk mengubah seluruh atau sebagian darinya, ke bentuk gas supaya bisa membuat adanya pembakaran.

\section{Fuzzy Sugeno}

Sistem logika fuzzy pertama kali diperkenalkan oleh Prof. L. A. Zadeh pada tahun 1965. Soft Computing merupakan inovasi baru dalam membangun sistem cerdas. Sistem cerdas ini merupakan sistem yang memiliki keahlian seperti manusia pada domain tertentu, mampu beradaptasi dan belajar agar dapat bekerja lebih baik jika terjadi perubahan lingkungan. Unsurunsur pokok dalam Soft Computing adalah: Sistem Fuzzy, Jaringan Saraf Tiruan, Probabilistic Reasoning, Evolutionary Computing (Salman, 2012) [4].

Dalam penerapan fuzzy sugeno terdapat proses-proses perhitungan yang digunakan, yaitu: menentukan nilai keanggotaan, fuzzyfikasi, inferensi, rule, dan defuzzyfikasi. Logika fuzzy memiliki derajat keanggotaan dalam rentang 0 hingga 1 . Berbeda dengan logika digital yang hanya memiliki dua nilai 1 atau 0 . Logika fuzzy digunakan untuk menerjemahkan suatu besaran yang diekspresikan menggunakan bahasa (linguistik), misalkan besaran kecepatan laju kendaraan yang diekspresikan dengan pelan, agak cepat, cepat, dan sangat cepat. Dan logika fuzzy menunjukan sejauh mana suatu nilai itu benar dan sejauh mana suatu nilai itu salah (Irfan dkk., 2018) [5].

\section{Fungsi Keanggotaan}

Dalam himpunan fuzzy terdapat beberapa representasi dari fungsi keanggotaan, salah satunya yaitu representasi linear. Pada representasi linear. Pada representasi linear pemetaan input ke derajat keanggotaanya digambarkan sebagai suatu garis lurus.

- Representasi Linear NAIK

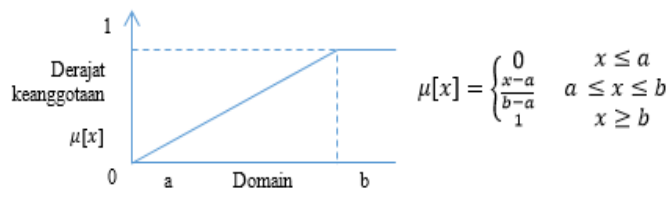

Gambar 2. Representasi Linear NAIK

- $\quad$ Representasi Linear TURUN

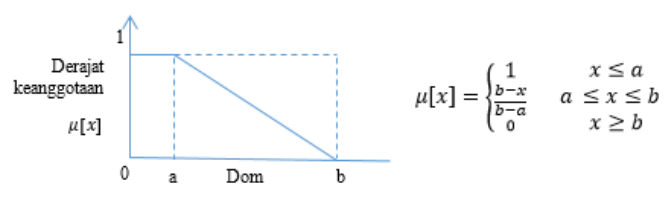

Gambar 3. Representasi Linear TURUN

Metode SUGENO secara umum menyerupai metode MAMDANI, akan tetapi output/konsekuen berupa konstanta atau persamaan linear.

1. Module Fuzzy Sugeno Orde-Nol

IF $(x 1$ is $\mathrm{Al}) *(\mathrm{x} 2 \text { is } \mathrm{A} 2)^{*} \ldots *(\mathrm{xn}$ is $\mathrm{An})$ THEN $\mathrm{z}=\mathrm{k}$

2. Model Fuzzy Sugeno Orde-Satu

IF $(\mathrm{xl}$ is $\mathrm{Al}) *(\mathrm{x} 2 \text { is } \mathrm{A} 2)^{*} \ldots *(\mathrm{xn}$ is $\mathrm{An}) \mathrm{THEN}$ $\mathrm{z}=\mathrm{pl}{ }^{*} \mathrm{z} 1+\ldots+\mathrm{pn} * \mathrm{xn}+\mathrm{q}$

\section{ESP32}

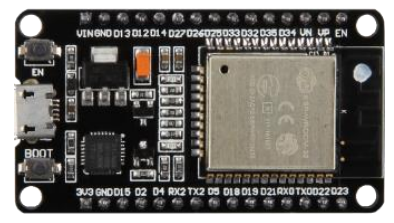

Gambar 4. ESP32

ESP32 merupakan penerus dari ESP8266 yang sering digunakan dalam pembuatan sistem Internet of Things (IoT). ESP32 memiliki DualCore 32 bit yang unggul diatasnya dari seri sebelumnya ESP8266 dan sudah dilengkapi dengan Bluetooth.

Spesifikasi dari ESP32:

1. Microprosesor Xtensa Dual-Core 32Bit LX6

2. Freq Clock up to $240 \mathrm{MHz}$

3. SRAM $520 \mathrm{kB}$

4. Flash memori $4 \mathrm{MB}$

5. $11 \mathrm{~b} / \mathrm{g} / \mathrm{n} \mathrm{WiFi}$ transceiver

6. Bluetooth 4.2/BLE

7. 48 pin $\mathrm{GPIO}$

8. 15 pin channel

\section{Sensor Deteksi Kebakaran}

Sensor dalam rangkaian akuisisi data dapat berupa komponen diskrit atau rangkaian terintegrasi (IC/Integrated Circuit). Pada umumnya untuk satu jenis parameter yang diukur melibatkan satu jenis sensor (Saptadi, 2014) [6]. 
INDEXIA: Informatic and Computational Intelegent Journal

Ervin Setyawan, Umi Chotijah, Henny Dwi Bhakti

Implementasi Pemadam Kebakaran Otomatis Pada Ruangan Menggunakan Pendeteksi Asap Suhu

Ruangan Dan Sensor Api Berbasis Esp32 Dengan Metode Fuzzy Sugeno Dan Internet Of Things (lot)

Deteksi kebakaran mempunyai berbagai macam sensor. Sensor yang paling banyak digunakan dalam deteksi kebakaran adalah: Sensor suhu, sensor asap, sensor api.

\section{Sensor Suhu DS18B20}

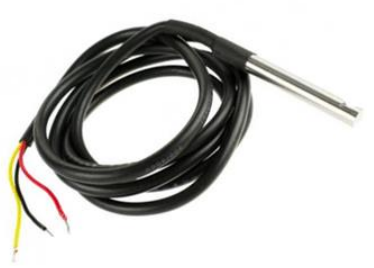

Gambar 5. Sensor Suhu DS18B20

Sensor Suhu DS18B20 adalah sensor suhu digital seri terbaru dari Maxim IC. Sensor ini mampu membaca suhu dengan ketelitian 9 hingga 12 -bit, rentang $-55^{\circ} \mathrm{C}-125^{\circ} \mathrm{C}$ dengan ketelitian $\left(+/-0.5^{\circ} \mathrm{C}\right)$.

Spesifikasi sensor suhu DS18B20:

1. Communicates over one-wire bus communication

2. Power supply range: $3.0 \mathrm{~V}$ to $5.5 \mathrm{~V}$

3. Operating temperature range: $-55^{\circ} \mathrm{C}$ to $+125^{\circ} \mathrm{C}$

4. Accuracy $+/-0.5^{\circ} \mathrm{C}$ (between the range $10^{\circ} \mathrm{C}$ to $85^{\circ} \mathrm{C}$ )

\section{Sensor Asap MQ2}

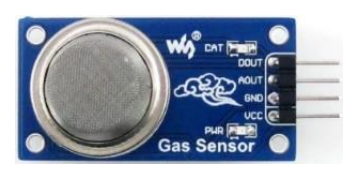

Gambar 6. Sensor Asap MQ2

Sensor Asap MQ2 merupakan sensor buatan Hanwei Electronics Semiconductor yang difungsikan untuk mengamati tingkat kontaminasi udara yang disebakan oleh asap rokok, asap pembakaran, dan gas gas lainnya yang mempunyai konsentrasi rendah seperti halnya Ammoniak, gan Gas H2S yang disebabkan dari asap hasil pembakaran material rumah tangga dan perkantoran. Sensor dapat mengukur konsentrasi gas mudah terbakar dari 300 sampai 10.000 sensor ppm. Pada sensor MQ2 Sensor MQ2 mempunyai tingkat sensitifitas yang tinggi terhadap perubahan gas (Utomo \& Saputra, 2016) [7]. Berikut range konsentrasi gas yang dapat diukur :

1. LPG dan Propana : 200ppm-5000ppm

2. Butana : $300 \mathrm{ppm}-5000 \mathrm{ppm}$

3. Metana : $5000 \mathrm{ppm}-20000 \mathrm{ppm}$

4. Hidrogen : 300ppm-5000ppm

5. Alkohol : 100ppm-2000ppm

Untuk sensitivitas sensor terhadap tipe gas di atas dapat dibaca pada Gambar kurva 7:

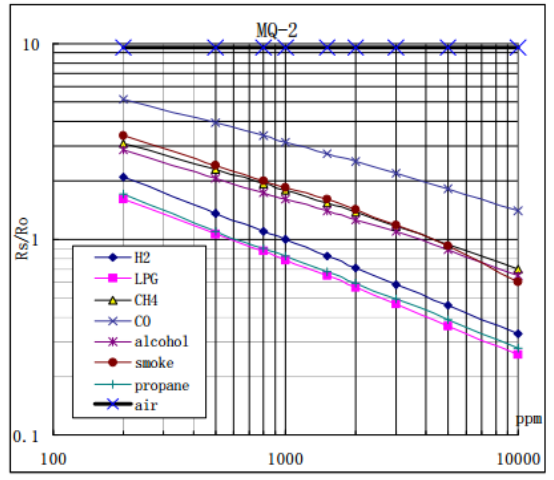

Gambar 7. Kurva Sensor MQ2

Sensor Api

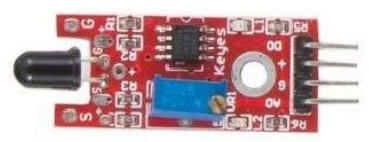

Gambar 8. Sensor Api

Sensor api bekerja pada tegangan 3.3V $12 \mathrm{~V}$. Sensor api memiliki sudut pembacaan sebesar $60 \square$, dan beroperasi pada suhu $-25^{\circ} \mathrm{C}$ $+85^{\circ} \mathrm{C}$. Sensor api juga memiliki 4 pin yaitu $\mathrm{Vcc}$, Gnd dan terdapat 2 jenis output yaitu, Digital Output (DO) dan Analog Output (AO). Apabila yang digunakan adalah pin Analog Output, maka data yang akan di tampilkan cukup banyak (Mudjiono \& Subekti, 2017) [8].

\section{Driver Motor L9110}

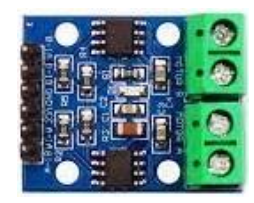

Gambar 9. Driver Motor L9110

Driver motor L9110 H-Bridge ini mempunyai 6 pins dan 2 channels. Di tengah pin terdapat pin VCC dan GND. L293 dan L298 mempunyai tegangan terpisah untuk motor, sedangkan L9110 tidak terpisah. L9110 ini memiliki tegangan $2.5-12 \mathrm{~V}$. Untuk 4 pin lainnya mengontrol arah dan kecepatan motor. Pin A-IA dan pin A-IB untuk mengendalikan motor A. Pin B-IA dan pin B-IB untuk mengendalikan motor B.

\section{Breadboard Power Supply MB102}


INDEXIA: Informatic and Computational Intelegent Journal

Ervin Setyawan, Umi Chotijah, Henny Dwi Bhakti

Implementasi Pemadam Kebakaran Otomatis Pada Ruangan Menggunakan Pendeteksi Asap Suhu

Ruangan Dan Sensor Api Berbasis Esp32 Dengan Metode Fuzzy Sugeno Dan Internet Of Things (lot)

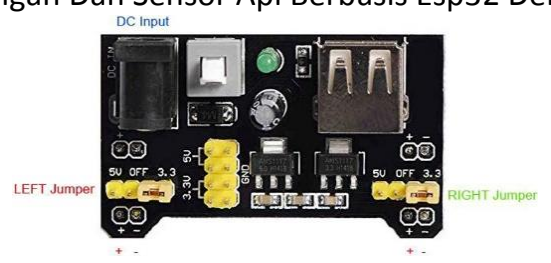

\section{Gambar 10. Breadboard Power Supply MB102}

Modul Breadboard Power Supply MB102 memiliki keluaran tegangan $3,3 \mathrm{~V} / 5 \mathrm{~V}$. Breadboard Power Supply ini yang paling mudah digunakan dikarenakan kemudahan penggunaannya dengan power supply DC dengan input $6.5-12 \mathrm{~V}$. Modul ini juga terdapat saklar tekan ON/OFF untuk mematikan dan menghidupkan power supply. Fitur tambahannya adalah input USB dengan dua pinout $5 \mathrm{~V}$, dua $3.3 \mathrm{~V}$, dan 4 GND untuk kebutuhan pin daya tambahan.

\section{Buzzer}

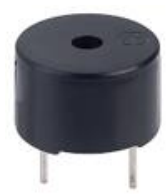

Gambar 11. Buzzer

Buzzer adalah sebuah komponen yang memiliki fungsi mengubah arus listrik menjadi suara. Dan pada dasarnya prinsip kerja buzzer hampir sama dengan speaker (Efrianto dkk., 2016) [9]. Buzzer ini memiliki tegangan 5v dan banyak digunakan pada alarm-alarm sistem Arduino.

\section{Pompa DC}

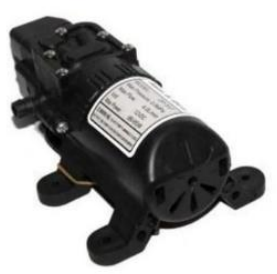

Gambar 12. Pompa DC

Pompa yang digunakan adalah pompa DC yang berukuran mini untuk digunakan dalam penyiraman terhadap api. Dengan ditenagai input sebesar $12 \mathrm{v}$.

\section{WhatsApp}

WhatsApp adalah aplikasi untuk mengirim pesan, menerima pesan, panggilan telepon, dan panggilan video dengan menggunakan sinyal internet tanpa perlu memakai pulsa. WhatsApp memiliki program lain yaitu WhatsApp Business yang digunakan untuk berjualan online, berbisnis dan banyak lagi. Untuk menggunakan IoT dengan memakai WhatsApp dibutuhkan sebuah API, WhatsApp sendiri untuk mendapatkan API memiliki 2 cara, cara yang pertama dengan melalui WhatsApp Business dan memerlukan pendaftaran. Cara yang kedua, melalui API pihak ketiga yang bisa di dapat di website-website penyedia API WhatsApp.

\section{IMPLEMENTASI DAN PENGUJIAN SISTEM \\ Impelemtasi Sistem}

Setelah sistem dianalisis dan dirancang secara rinci, tahap selanjutnya adalah implementasi. Implementasi dilakukan sesuai dengan perancangan yang sudah dilakukan sebelumnya. Berikut ini adalah gambar hasil perancangan sistem pemadam kebakaran yang telah dibuat:

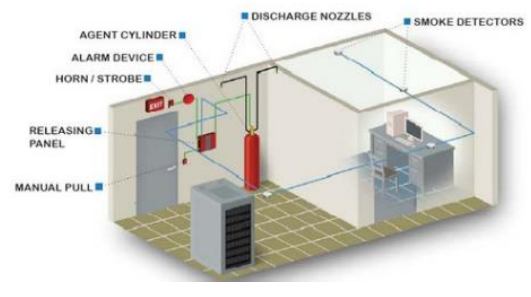

Gambar 13. Sistem Pemadam Kebakaran

\section{Pengujian Sistem}

Pengujian sistem merupakan hal terpenting yang bertujuan untuk menemukan kesalahankesalahan atau kekurangan-kekurangan pada sistem yang akan diuji. Pengujian bermaksud untuk mengetahui sistem yang dibuat telah memenuhi kinerja sesuai dengan tujuan perancangan.

Berdasarkan rencana pengujian yang telah disusun, maka dapat dilakukan pengujian sebagai berikut.

\section{Pengujian Sensor Asap MQ2}

Pada pengujian pertama, dilakukan pengujian akuisisi data pada sensor MQ2 dalam mendeteksi kadar asap atau gas dalam satuan ppm. Pembacaan tersebut dilakukan dengan cara membuat sumber asap yang berasal dari hasil pembakaran barang yang dapat menghasilkan asap. Output dari pembacaan sensor dilihat melalui serial monitor pada Arduino IDE. Hasil 
INDEXIA: Informatic and Computational Intelegent Journal

Ervin Setyawan, Umi Chotijah, Henny Dwi Bhakti

Implementasi Pemadam Kebakaran Otomatis Pada Ruangan Menggunakan Pendeteksi Asap Suhu

Ruangan Dan Sensor Api Berbasis Esp32 Dengan Metode Fuzzy Sugeno Dan Internet Of Things (lot)

dari pengujian sensor MQ2 dapat dilihat pada

Tabel 1.

Tabel 1. Hasil pengujian akuisisi data sensor asap MQ2.

\begin{tabular}{|c|c|c|c|}
\hline No & Kondisi & $\begin{array}{c}\text { Nilai } \\
\text { Sensor } \\
\text { ADC } \\
\text { MQ2 } \\
\end{array}$ & $\begin{array}{c}\text { Nilai } \\
\text { PPM } \\
\text { Sensor } \\
\text { MQ2 }\end{array}$ \\
\hline 1 & \multirow{3}{*}{ Normal } & 188 & 2082 \\
\hline 2 & & 199 & 2186 \\
\hline 3 & & 200 & 2196 \\
\hline 4 & \multirow{3}{*}{$\begin{array}{l}\text { Terdapat } \\
\text { asap }\end{array}$} & 301 & 3154 \\
\hline 5 & & 341 & 3533 \\
\hline 6 & & 425 & 4329 \\
\hline 7 & \multirow{4}{*}{$\begin{array}{c}\text { disetiap } \\
\text { sensor } \\
\text { dengan } \\
\text { variasi }\end{array}$} & 484 & 4889 \\
\hline 8 & & 540 & 5420 \\
\hline 9 & & 572 & 5723 \\
\hline 10 & & 620 & 6178 \\
\hline 11 & \multirow{3}{*}{$\begin{array}{c}\text { kepekatan } \\
\text { yang } \\
\text { berbeda }\end{array}$} & 683 & 6776 \\
\hline 12 & & 710 & 7032 \\
\hline 13 & & 824 & 8113 \\
\hline 14 & \multirow{3}{*}{$\begin{array}{l}\text { Asap } \\
\text { mulai } \\
\text { terurai }\end{array}$} & 283 & 2983 \\
\hline 15 & & 223 & 2414 \\
\hline 16 & & 189 & 2092 \\
\hline
\end{tabular}

\section{Pengujian Sensor Suhu DS18B20}

Tahap kedua adalah pengujian sensor suhu DS18B20. Tujuan dari pengujian ini adalah mengetahui sistem error dari sensor jika dibandingkan dengan termometer.

Pembacaan suhu tersebut dilakukan dengan cara memberikan suhu panas dari api lilin untuk meningkatkan pembacaan suhu. Hasil dari pengujian sensor DS18B20 dapat dilihat pada Tabel 2.

Tabel 2. Hasil pengujian akuisisi data sensor suhu DS18B20.

\begin{tabular}{|c|c|c|c|}
\hline Percobaan & $\begin{array}{c}\text { Pembacaan } \\
\text { Termometer } \\
\left({ }^{\circ} \mathrm{C}\right)\end{array}$ & $\begin{array}{c}\text { Pembacaan } \\
\text { Sensor } \\
\text { DS18B20 } \\
\left({ }^{\circ} \mathrm{C}\right)\end{array}$ & $\begin{array}{c}\text { Error } \\
\%\end{array}$ \\
\hline 1 & 30,6 & 30 & 0,6 \\
\hline 2 & 31,2 & 31 & 0,2 \\
\hline 3 & 32,1 & 32 & 0,1 \\
\hline 4 & 34,1 & 33 & 1,1 \\
\hline 5 & 35,4 & 35 & 0,4 \\
\hline 6 & 36,7 & 36 & 0,7 \\
\hline 7 & 38,1 & 37 & 1,1 \\
\hline 8 & 40,1 & 38 & 2,1 \\
\hline 9 & 41,6 & 40 & 1,6 \\
\hline 10 & 45,4 & 43 & 2,4 \\
\hline \multicolumn{4}{|r}{ Rata-rata } \\
\hline
\end{tabular}

\section{Pengujian Sensor Api}

Pengujian tahap ketiga yaitu pengujian sensor api. Pengujian dilakukan di dalam ruangan menggunakan sumber api dari 1 buah

lilin dengan sudut antara sensor dan lilin tegak lurus $90^{\circ}$. Data masukan yang digunakan dalam pengujian adalah jarak antara api dan sensor, sedangkan data keluarannya adalah nilai ADC yang dihasilkan. Hasil dari pengujian sensor api dapat dilihat pada Tabel 3.

Tabel 3. Hasil pengujian akuisisi data sensor api.

\begin{tabular}{|c|c|c|}
\hline No & Nilai ADC Sensor Api & $\begin{array}{c}\text { Jarak Api } \\
\text { Dengan } \\
\text { Sensor }\end{array}$ \\
\hline 1 & 68 & $20 \mathrm{~cm}$ \\
\hline 2 & 73 & $30 \mathrm{~cm}$ \\
\hline 3 & 82 & $60 \mathrm{~cm}$ \\
\hline 4 & 96 & $70 \mathrm{~cm}$ \\
\hline 5 & 230 & $80 \mathrm{~cm}$ \\
\hline 6 & 424 & $90 \mathrm{~cm}$ \\
\hline 7 & 650 & $120 \mathrm{~cm}$ \\
\hline
\end{tabular}

\section{Pengujian Metode Fuzzy Sugeno}

Pengujian keempat dilakukan dengan metode pengujian fuzzy sugeno pada sistem dalam menentukan output. Tujuan dari metode pengujian ini adalah untuk mengetahui apakah metode fuzzy yang diterapkan pada sistem sesuai dengan perancangan. Berdasarkan pengujian yang dilakukan, maka didapatkan hasil pembacaan sensor seperti pada Tabel 4.

Tabel 4. Hasil Pengujian Proses Fuzzy Sugeno

\begin{tabular}{|c|c|c|c|c|c|}
\hline $\begin{array}{c}\text { N } \\
\text { o }\end{array}$ & $\begin{array}{c}\text { Pemba } \\
\text { caan } \\
\text { Sensor } \\
\text { MQ2 }\end{array}$ & $\begin{array}{c}\text { Pemba } \\
\text { caan } \\
\text { Sensor } \\
\text { DS18B } \\
20\end{array}$ & $\begin{array}{c}\text { Pemba } \\
\text { caan } \\
\text { Sensor } \\
\text { Api }\end{array}$ & $\begin{array}{c}\text { Out } \\
\text { put } \\
\text { Sist } \\
\text { em }\end{array}$ & $\begin{array}{c}\text { Outp } \\
u t \\
\text { Seca } \\
\text { ra } \\
\text { Man } \\
\text { ual }\end{array}$ \\
\hline 1 & 492 & $31^{\circ} \mathrm{C}$ & 102 & 2,02 & 2,02 \\
\hline 2 & 284 & $33^{\circ} \mathrm{C}$ & 396 & 1,00 & 1,00 \\
\hline 3 & 547 & $34^{\circ} \mathrm{C}$ & 426 & 1,58 & 1,58 \\
\hline 4 & 328 & $34^{\circ} \mathrm{C}$ & 92 & 1,94 & 1,94 \\
\hline 5 & 474 & $34^{\circ} \mathrm{C}$ & 82 & 2,53 & 2,53 \\
\hline 6 & 456 & $35^{\circ} \mathrm{C}$ & 268 & 2,07 & 2,07 \\
\hline 7 & 243 & $36^{\circ} \mathrm{C}$ & 1023 & 1,00 & 1,00 \\
\hline 8 & 842 & $37^{\circ} \mathrm{C}$ & 430 & 1,86 & 1,86 \\
\hline 9 & 568 & $43^{\circ} \mathrm{C}$ & 254 & 2,86 & 2,86 \\
\hline 1 & 721 & $46^{\circ} \mathrm{C}$ & 173 & 3,00 & 3,00 \\
0 & & & & & \\
\hline
\end{tabular}

Berdasarkan pengujian tersebut, dapat dianalisis bahwa rumus fuzzy yang digunakan pada sistem benar dan tepat. Hal ini dapat dilihat dari 10 percobaan dengan input yang berbeda pada tabel memberikan output sistem yang sama dan sesuai dengan perancangan. Hal tersebut ditunjukan pada analisis hasil pengujian di Tabel 5.

Tabel 5. Analisis tingkat keakuratan Metode 
INDEXIA: Informatic and Computational Intelegent Journal

Ervin Setyawan, Umi Chotijah, Henny Dwi Bhakti

Implementasi Pemadam Kebakaran Otomatis Pada Ruangan Menggunakan Pendeteksi Asap Suhu

Ruangan Dan Sensor Api Berbasis Esp32 Dengan Metode Fuzzy Sugeno Dan Internet Of Things (lot)

\begin{tabular}{|l|l|}
\hline $\begin{array}{l}\text { Nilai Kesesuaian perhitungan Output } \\
\text { fuzzy }\end{array}$ & 10 \\
\hline Nilai Output fuzzy tidak sesuai & 0 \\
\hline Tingkat Keakuratan Perhitungan Metode & $100 \%$ \\
\hline
\end{tabular}

\section{Pengujian Pompa DC dan Buzzer}

Pengujian kelima yaitu pengujian pada pompa dan buzzer dengan memberikan hasil nilai $\mathrm{Z}$ (defuzzyfikasi) sehingga dapat diketahui durasi (detik) penyiraman pompa air dan nyala buzzer (alarm). Hasil dari pengujian pompa dan buzzer dapat dilihat pada Tabel 6 .

Tabel 6. Hasil pengujian pompa dan buzzer.

\begin{tabular}{|c|c|c|c|c|}
\hline $\begin{array}{c}\mathrm{N} \\
\mathrm{o}\end{array}$ & $\begin{array}{c}\text { Kondi } \\
\text { si } \\
\text { Pomp } \\
\mathrm{a}\end{array}$ & $\begin{array}{c}\text { Kondi } \\
\text { si } \\
\text { Buzze } \\
\mathrm{r}\end{array}$ & $\begin{array}{c}\text { Nilai Z } \\
\text { (Defuzzyfik } \\
\text { asi) }\end{array}$ & $\begin{array}{c}\text { Waktu } \\
\text { Pemadam } \\
\text { an }\end{array}$ \\
\hline 1 & Mati & OFF & 1,00 & - \\
\hline 2 & Cepat & ON & $2,00-2,99$ & 7 Detik \\
\hline 3 & Lama & ON & 3,00 & 15 Detik \\
\hline
\end{tabular}

\section{Pengujian Notifikasi WhatsApp}

Pengujian keenam adalah pengujian terhadap notifikasi aplikasi whatsapp untuk mengetahui terjadinya kebakaran. Pengujian dilakukan dengan input dari ketiga sensor untuk mendapatkan hasil akhir dari nilai $\mathrm{Z}$ (defuzzyfikasi). Dilakukan pengujian 2 tahapan yaitu, nilai hasil akhir $Z$ antara 2 dan 3. Pengujian pertama dengan mendapatkan nilai $Z$ yaitu 2,02 dan pengujian kedua didapatkan nilai $\mathrm{Z}$ yaitu 3,00. Hasil dari pengujian notifikasi whatsapp dapat dilihat pada Gambar 14.

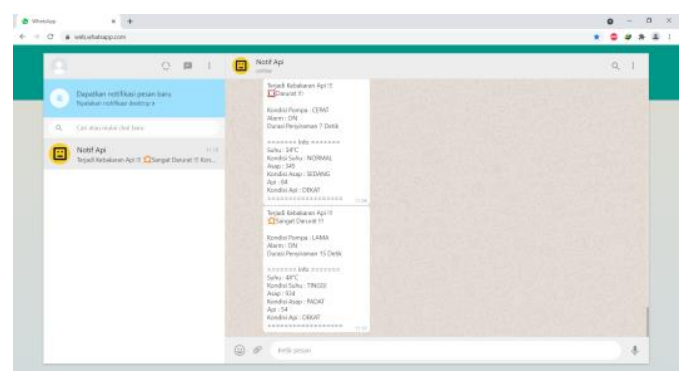

Gambar 14. Pengujian notifikasi whatsapp

Pada pengujian notifikasi whatsapp yang dilakukan, maka didapatkan hasil pembacaan sensor seperti pada Tabel 7.

Tabel 7. Hasil pengujian notifikasi whatsapp.

\begin{tabular}{|c|c|c|c|c|c|}
\hline $\begin{array}{l}\mathrm{N} \\
\mathrm{o}\end{array}$ & $\begin{array}{l}\text { Pemba } \\
\text { caan } \\
\text { Sensor } \\
\text { MQ2 }\end{array}$ & $\begin{array}{c}\text { Pemba } \\
\text { caan } \\
\text { Sensor } \\
\text { DS18B } \\
20\end{array}$ & $\begin{array}{l}\text { Pemba } \\
\text { caan } \\
\text { Sensor } \\
\text { Api }\end{array}$ & $\begin{array}{l}\text { Out } \\
\text { put } \\
\text { Sist } \\
\text { em }\end{array}$ & $\begin{array}{l}\text { Notifik } \\
\text { asi } \\
\text { Whats } \\
\text { App } \\
\text { (Ya/Ti } \\
\text { dak) }\end{array}$ \\
\hline 1 & 345 & $34^{\circ} \mathrm{C}$ & 84 & 2,02 & $\mathrm{Ya}$ \\
\hline 2 & 934 & $48^{\circ} \mathrm{C}$ & 76 & 3,00 & $\mathrm{Ya}$ \\
\hline
\end{tabular}

\section{Pengujian Sistem Pemadam Kebakaran}

Pengujian sistem pemadam kebakaran bertujuan untuk mengetahui kinerja sistem dalam mengeksekusi input menjadi output sesuai dengan perhitungan fuzzy. Pengujian dilakukan dengan membuat kebakaran ringan pada sebuah kotak yang telah didesain untuk proses pengujian seperti pada Gambar 15.

Perhitungan sistem pemadam kebakaran yang dihasilkan dengan durasi penyiraman pompa. Berdasarkan pengujian yang dilakukan, maka didapatkan hasil seperti pada Tabel 8.

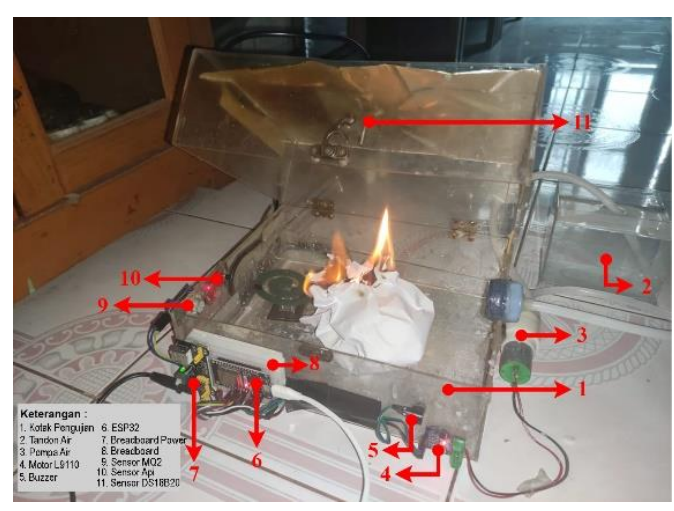

Gambar 15. Proses pengujian sistem pemadam kebakaran

Pada pengujian sistem pemadam kebakaran yang dilakukan, maka didapatkan hasil pengujian seperti pada Tabel 8.

Tabel 8. Hasil pengujian sistem pemadam kebakaran.

\begin{tabular}{|c|c|c|c|c|c|c|c|}
\hline No & $\begin{array}{c}\text { Input } \\
\text { MQ2 }\end{array}$ & $\begin{array}{c}\text { Input } \\
\text { DS1 } \\
8 \mathrm{~B} 20\end{array}$ & $\begin{array}{c}\text { Input } \\
\text { Api }\end{array}$ & $\begin{array}{c}\text { Outp } \\
u t \\
\text { Fuzz } \\
\mathrm{y}\end{array}$ & $\begin{array}{c}\text { Kond } \\
\text { isi } \\
\text { Pom } \\
\mathrm{pa}\end{array}$ & $\begin{array}{c}\text { Dura } \\
\text { si } \\
\text { Peny } \\
\text { ram } \\
\text { an }\end{array}$ & $\begin{array}{c}\text { Notif } \\
\text { ikasi } \\
\text { What } \\
\text { sApp } \\
\text { (Ya/ } \\
\text { Tida } \\
\mathrm{k})\end{array}$ \\
\hline 1 & 186 & $31^{\circ} \mathrm{C}$ & 576 & 1,00 & Mati & - & $\begin{array}{c}\text { Tida } \\
\mathrm{k}\end{array}$ \\
\hline 2 & 352 & $32^{\circ} \mathrm{C}$ & 1023 & 1,00 & Mati & - & $\begin{array}{c}\text { Tida } \\
\mathrm{k}\end{array}$ \\
\hline 3 & 262 & $32^{\circ} \mathrm{C}$ & 656 & 1,00 & Mati & - & $\begin{array}{c}\text { Tida } \\
\mathrm{k}\end{array}$ \\
\hline 4 & 225 & $32^{\circ} \mathrm{C}$ & 682 & 1,00 & Mati & - & $\begin{array}{c}\text { Tida } \\
\mathrm{k}\end{array}$ \\
\hline 5 & 249 & $33^{\circ} \mathrm{C}$ & 597 & 1,00 & Mati & - & $\begin{array}{c}\text { Tida } \\
\mathrm{k}\end{array}$ \\
\hline 6 & 383 & $36^{\circ} \mathrm{C}$ & 543 & 1,32 & Mati & - & $\begin{array}{c}\text { Tida } \\
\mathrm{k}\end{array}$ \\
\hline 7 & 336 & $38^{\circ} \mathrm{C}$ & 424 & 1,40 & Mati & - & $\begin{array}{c}\text { Tida } \\
\mathrm{k}\end{array}$ \\
\hline
\end{tabular}


INDEXIA: Informatic and Computational Intelegent Journal

Ervin Setyawan, Umi Chotijah, Henny Dwi Bhakti

Implementasi Pemadam Kebakaran Otomatis Pada Ruangan Menggunakan Pendeteksi Asap Suhu

Ruangan Dan Sensor Api Berbasis Esp32 Dengan Metode Fuzzy Sugeno Dan Internet Of Things (lot)

\begin{tabular}{|c|c|c|c|c|c|c|c|}
\hline 8 & 355 & $42^{\circ} \mathrm{C}$ & 60 & 2,81 & $\begin{array}{c}\text { Cepa } \\
\text { t }\end{array}$ & $\begin{array}{c}7 \\
\text { Detik }\end{array}$ & Ya \\
\hline 9 & 306 & $43^{\circ} \mathrm{C}$ & 132 & 2,50 & $\begin{array}{c}\text { Cepa } \\
\text { t }\end{array}$ & $\begin{array}{c}7 \\
\text { Detik }\end{array}$ & Ya \\
\hline 10 & 548 & $41^{\circ} \mathrm{C}$ & 341 & 2,63 & $\begin{array}{c}\text { Cepa } \\
\text { t }\end{array}$ & $\begin{array}{c}7 \\
\text { Detik }\end{array}$ & Ya \\
\hline 11 & 326 & $45^{\circ} \mathrm{C}$ & 318 & 2,30 & $\begin{array}{c}\text { Cepa } \\
\text { t }\end{array}$ & $\begin{array}{c}7 \\
\text { Detik }\end{array}$ & Ya \\
\hline 12 & 488 & $47^{\circ} \mathrm{C}$ & 481 & 2,25 & $\begin{array}{c}\text { Cepa } \\
\text { t }\end{array}$ & $\begin{array}{c}7 \\
\text { Detik }\end{array}$ & Ya \\
\hline 13 & 608 & $50^{\circ} \mathrm{C}$ & 427 & 2,62 & $\begin{array}{c}\text { Cepa } \\
\text { t }\end{array}$ & $\begin{array}{c}7 \\
\text { Detik }\end{array}$ & Ya \\
\hline 14 & 763 & $52^{\circ} \mathrm{C}$ & 260 & 3,00 & $\begin{array}{c}\text { Lam } \\
\text { a }\end{array}$ & $\begin{array}{c}15 \\
\text { Detik }\end{array}$ & Ya \\
\hline 15 & 672 & $57^{\circ} \mathrm{C}$ & 91 & 3,00 & $\begin{array}{c}\text { Lam } \\
\text { a }\end{array}$ & $\begin{array}{c}15 \\
\text { Detik }\end{array}$ & Ya \\
\hline
\end{tabular}

[2] Arfah, H. (2017). Polisi Dalami Penyebab Kebakaran Pasar Gresik. https://regional.kompas.com/read/2017/0 2/04/13120901/polisi.dalami.penyebab.k ebakaran.pasar.gresik.

Dari hasil pengujian eksekusi sistem menunjukkan bahwa hasil eksekusi setiap output berbeda. Hal ini disebabkan oleh komputasi fuzzy yang diterapkan berdasarkan input dari tiap sensor. Terjadi perbedaan pada durasi penyiraman dari setiap situasi kebakaran yang terjadi, hal ini berpengaruh juga pada kondisi sebuah pompa.

\section{KESIMPULAN}

Dengan melihat hasil penelitian yang telah dibahas, maka dapat kita tarik kesimpulan sebagai berikut:

1. Untuk mendeteksi adanya nyala api dibutuhkan sensor api.

2. Proses perancangan Sistem Pemadam Kebakaran adalah dengan menghubungkan sensor MQ2, DS18B20 dan sensor api dengan mikrokontroler ESP32.

3. Sistem akan bekerja sesuai perhitungan metode fuzzy sugeno dan mengirimkan notifikasi whatsapp ketika tiga sensor mendeteksi adanya asap, perubahan suhu, dan terdapat api.

4. Pompa dihitung dengan output metode fuzzy sugeno dalam tindakan pemadaman api.

\section{SARAN}

Berdasarkan hasil penelitian, pembahasan dan pengujian pada Sistem Pemadam Kebakaran dengan metode fuzzy sugeno, dapat diberikan saran-saran untuk pengembangan penelitian selanjutnya yaitu:

1. Menggunakan sensor asap dan api yang memiliki sensitivitas yang tinggi.

2. Penambahan lebih banyak sprinkler agar lebih cepat dalam penyiraman dengan tingkat kebakaran yang lebih tinggi.

\section{DAFTAR PUSTAKA}

[1] Romadhon, B. (2018). Analisis Proteksi Kebakaran Pada Perusahaan Produksi Gas Dan Pembangkit Listrik. The Indonesian Journal of Occupational Safety and Health, 7(2), 142. https://doi.org/10.20473/ijosh.v7i2.2018. 142-151.

[3] Supriyadi, E. (2020). Rancang Bangun Alarm Pendeteksi Kebakaran Pada Gedung Bertingkat Menggunakan Metode Logika Fuzzy Berbasis. XXII(2), 10-20. https://ejournal.istn.ac.id/index.php/sinus oida/article/view/695.

[4] Salman, A. G. (2012). Pemodelan Dasar Sistem Fuzzy. https://socs.binus.ac.id/2012/03/02/pemo delan-dasar-sistem-fuzzy/.

[5] Irfan, M., Ayuningtias, L. P., \& Jumadi, J. (2018). Analisa Perbandingan Logic Fuzzy Metode Tsukamoto, Sugeno, Dan Mamdani ( Studi Kasus : Prediksi Jumlah Pendaftar Mahasiswa Baru Fakultas Sains Dan Teknologi Uin Sunan Gunung Djati Bandung). Jurnal Teknik Informatika, 10(1), 9-16. https://doi.org/10.15408/jti.v10i1.6810.

[6] Saptadi, A. H. (2014). Perbandingan Akurasi Pengukuran Suhu dan Kelembaban Antara Sensor DHT11 dan DHT22. JURNAL INFOTEL - Informatika Telekomunikasi Elektronika, 6(2), 49. https://doi.org/10.20895/infotel.v6i2.16.

[7] Utomo, B. T. W., \& Saputra, D. S. (2016). Simulasi Sistem Pendeteksi Polusi Ruangan Menggunakan Sensor Asap Dengan Pemberitahuan Melalui SMS (Short Message Service) Dan Alarm Berbasis Arduino. Jurnal Ilmiah Teknologi Informasi Asia, 10(1), 56-68. https://jurnal.stmikasia.ac.id/index.php/ji tika/article/view/76.

[8] Mudjiono, U., \& Subekti, A. (2017). Fire Spot Detector untuk Deteksi Dini Terjadinya Kebakaran di Kapal. Seminar MASTER PPNS, 2(1), 229-234. http://journal.ppns.ac.id/index.php/Semin arMASTER/article/view/300.

[9] Efrianto, Ridwan, \& Fahruzi, I. (2016). Sistem Pengaman Motor Menggunakan Smartcard Politeknik Negeri Batam Electrical Engineering study Program. Integrasi, $\quad 8(1), \quad 1-5$. 
INDEXIA: Informatic and Computational Intelegent Journal

Ervin Setyawan, Umi Chotijah, Henny Dwi Bhakti

Implementasi Pemadam Kebakaran Otomatis Pada Ruangan Menggunakan Pendeteksi Asap Suhu

Ruangan Dan Sensor Api Berbasis Esp32 Dengan Metode Fuzzy Sugeno Dan Internet Of Things (lot)

https://jurnal.polibatam.ac.id/index.php/J

I/article/view/46. 